\title{
Perilaku Pencarian Informasi Siswa Dalam Model Pembelajaran Jarak Jauh di Masa Pandemi Covid-19
}

\author{
Mindy Syailah Nurthoyyibah \\ Program Studi Perpustakaan dan Sains Informasi, Universitas Pendidikan Indonesia \\ E-mail: syailahmindy@upi.edu \\ Susanti Agustina \\ Program Studi Perpustakaan dan Sains Informasi, Universitas Pendidikan Indonesia \\ E-mail: susanti@upi.edu
}

Received: 18-10-2021

Revised: 15-11-2021

Accepted: 27-12-2021

DOI: 10.24036/ib.v3i1.278

\begin{abstract}
The pandemic Covid-19 has impact most of human activities, one of them is education. The implementation of distance learning has influence for the parents, teachers, and students who are the main subjects in education, as though increased stress, less of competency development, or technical learning problems related to fulfill information needs. In case the problems abandoned, it will hinder the studentsdevelopment, the development of sustainable education, and the progress of the nation. This research aims to determine the information behavior of students of SMAN 1 Cicalengka in overcome learning constraints during the pandemic Covid-19. This research uses a qualitative approach with descriptive methods. Data collection techniques is using triangulation data, through observation/surveys, interviews, and literature study. The population were all students of SMAN 1 Cicalengka with 5 informants. It uses the OhotshiGottschalg-Duque information-behavior model as conceptual framework. The results showed that: First, students information needs were at the concious, visceral, and adapted levels; Second, information needs are mostly related with learning materials, motivation, health, hobbies, college even job vacancies; Third, students information behavior based on habits and intuitions, most of students do not understand the process of extracting because they do not recognize the domain of the information need. The implication that learning based on library is necessity at the level of educational unit that collaborates between teachers and school librarians.
\end{abstract}

Keywords: literacy; learning problems; the covid-19 pandemic; information behavior; school library.

\begin{abstract}
Abstrak
Pandemi Covid-19 berdampak terhadap sebagian besar aktivitas manusia, salah satunya dunia pendidikan. Pelaksanaan pembelajaran jarak jauh (PJJ) memberikan dampak bagi orang tua, guru, dan siswa yang merupakan subjek utama dalam pendidikan, seperti terjadinya peningkatan stres, kurang berkembangnya kompetensi, masalah belajar secara teknis berkaitan dengan pemenuhan kebutuhan informasi. Apabila dibiarkan akan menghambat perkembangan diri siswa, pengembangan pendidikan berkelanjutan, dan kemajuan bangsa. Penelitian ini bertujuan untuk mengetahui perilaku pencarian informasi siswa SMAN 1 Cicalengka dalam mengatasi masalah belajar di masa pandemi Covid-19. Penelitian ini menggunakan pendekatan kulitatif dengan metode deskriptif. Teknik pengumpulan data menggunakan triangulasi data, melalui observasi/survei, wawancara, dan studi pustaka. Populasi yaitu seluruh siswa SMAN 1 Cicalengka dengan informan sejumlah 5 orang. Penelitian ini menggunakan model perilaku pencarian informasi Ohotshi-Gottschalg-Duque sebagai kerangka konseptualnya. Hasil penelitian menunjukkan: Pertama, kebutuhan informasi siswa berada pada level concious, visceral, dan adapted; Kedua, kebutuhan informasi sebagian besar terkait materi pembelajaran, motivasi, kesehatan, hobi, perkuliahan bahkan lowongan pekerjaan; Ketiga, pencarian informasi siswa berdasarkan
\end{abstract}


Published by Program Studi Perpustakaan dan IImu Informasi

FBS Universitas Negeri Padang, Indonesia

kebiasaan dan intuisi, sebagian besar siswa kurang memahami proses extracting karena mereka belum memahami domain yang tepat atas informasi yang diperlukannya. Implikasi dari penelitian ini adalah pembelajaran perpustakaan diperlukan di tingkat satuan pendidikan bekerja sama antara guru dan pustakawan sekolah.

Kata Kunci: literasi; masalah belajar; pandemi Covid-19; perilaku pencarian informasi; perpustakaan sekolah.

\section{PENDAHULUAN}

Pada akhir tahun Desember 2019 terjadi suatu fenomena yang pada saat itu belum mampu menggerakan manusia secara alam bawah sadar akan bahaya yang mengintainya, sebelum dengan pasti terlihat oleh mata kepala. Fenomena itu adalah Coronavirus Disease 19 atau sering kali disebut dengan Covid-19, yang awal penyebarannya dari kelelawar di daratan Cina. Karena penyebarannya yang sangat cepat dan meluas itulah dinamakan dengan pandemi.

Penyebarannya terus berlanjut hingga sebagian besar negara menutup berbagai akses dari pihak eksternal bahkan pihak internal pada bidang ekonomi, sosial, budaya, agama dan pendidikan. Penutupan akses tersebut dinamakan dengan kuncitara atau lockdown. Setiap harinya korban terus bertambah, begitupun di Indonesia yang tercatat per 18 November 2020 terdapat 478.720 orang kasus positif, 402.347 orang kasus sembuh dan 15.503 orang kasus meninggal dunia (Covid-19.go.id, 2020). Seiring dengan pertumbuhan korban yang bertambah pesat muncul berbagai edaran dari pemerintah Indonesia terkait dengan pembatasan sosial, karantina wilayah bahkan berdampak pada dunia pendidikan, dengan penetapan pembelajaran jarak jauh (PJJ). Kemendikbud mengeluarkan Surat Edaran No.4 tahun 2020 tentang Pelaksanaan Pendidikan Dalam Masa Darurat Coronavirus Disease 19 (Covid19) dalam upaya menekan angka penyebaran virus, khususnya di lingkungan sekolah.

Pelaksanaan pembelajaran jarak jauh (PJJ) memberikan banyak dampak baik bagi orang tua, guru bahkan siswa yang merupakan subjek utama dalam pendidikan. Seperti peningkatan stres, kurang berkembangnya kompetensi 
dan kendala belajar lainnya yang jika dibiarkan begitu saja akan memberikan dampak yang buruk bagi perkembangan diri, pendidikan bahkan negara. Berbagai keluhan masyarakat mulai marak disampaikan oleh pendidik maupun peserta didik baik di lini media sosial, layanan informasi masyarakat maupun perbincangan santai di serambi rumah.

Berkaitan dengan akses belajar, pencarian informasi merupakan suatu kegiatan rutin yang dilakukan oleh seseorang dalam memenuhi informasi yang dibutuhkan. Concise Dictionary of Library and Information Science dalam Shenton and Hay-Gibson (2011) mengungkapkan bahwa pencarian informasi adalah "process of searching a collection of items in order to identify those documents that deal with a particular subject". Hal ini didukung dengan pernyataan dari Ridlo, Pasaribu, dan Tarigan (2020) yang mengungkapkan bahwa seseorang melakukan pencarian informasi karena merasa perlu dalam upaya memenuhi kebutuhannya melalui berbagai sumber dengan mudah.
Perilaku pencarian informasi tersebut juga berlaku di lingkungan sekolah, khususnya Sekolah Menengah Atas Negeri 1 Cicalengka. Pencarian informasi dalam memenuhi perannya sebagai peserta didik aktif dalam pembelajaran jarak jauh (PJJ) menarik untuk diteliti. Terlebih di masa pandemi Covid-19 ini seluruh pihak dituntut secara aktif untuk melek terhadap teknologi dimana semua informasi untuk saat ini beralih digital karena keterbatasan akses. Dengan melihat fenomena saat ini bahwa meskipun perkembangan teknologi informasi sudah maju, namun siswa SMAN 1 Cicalengka masih mendapati kendala belajar dalam program pembelajaran jarak jauh (PJJ).

Hasil wawancara terhadap guru di SMAN 1 Cicalengka, diketahui bahwa peserta didik di sekolah tersebut sebagian besar melakukan pencarian informasi melalui platform mesin pencarian Google. Hanya saja hasil pencarian informasi peserta didik melalui Google belum menunjukkan kualitas dan kesesuaian informasi yang sejatinya diharapkan mendukung 
perkembangan bidang ilmu pasti (saintek). Peserta didik belum mampu menemukan informasi yang sesuai dengan konteks pembelajaran, contohnya salah menerapkan teori. Hal ini memberikan pertanyaan besar di benak para pendidik, mengenai apa sebenarnya yang kurang tepat.

Pertanyaan mengenai “apakah terdapat kesalahan dari pihak guru yang kurang peka terhadap pembaharuan keilmuan?”, “apakah kesalahan siswa yang kurang peka terhadap ilmu yang dipelajari”, atau "apakah ada kesalahan ketika menerapkan strategi dalam pencarian informasi yang selama ini dilaksanakan?".

Pertanyaan di atas diperkuat dengan hasil survei awal yang dilakukan oleh peneliti mengenai persepsi para siswa SMAN 1 Cicalengka dalam menjalankan Pembelajaran Jarak Jauh (PJJ), yang mengungkapkan bahwa 61\% siswa mudah bosan, $90 \%$ siswa memiliki kesulitan untuk fokus, 51\% siswa kurang motivasi, 59\% siswa kesulitan dalam mengatur waktu tugas serta $12 \%$ siswa kurang memahami materi yang disampaikan oleh pendidik. Berdasarkan uraian di atas, maka perumusan masalah yang muncul dalam penelitian ini adalah "Bagaimana perilaku pencarian informasi yang dilaksanakan oleh siswa SMAN 1 Cicalengka dalam mengatasi kendala belajar di masa pandemi?"

\section{METODE}

Penelitian ini merupakan penelitian kualitatif deskriptif. Menurut Susilana (2012) bahwa pendekatan kualitatif deskriptif berorientasi pada fenomena yang bersifat alami yang digambarkan secara jelas, luas dan tajam berdasarkan bukti-bukti yang ada. Penelitian ini dilaksanakan di Sekolah Menengah Atas Negeri 1 Cicalengka, Kabupaten Bandung Timur. Populasinya adalah seluruh siswa yang mengalami kendala belajar. Teknik sampling yang digunakan adalah purposive sampling dengan pertimbangan kriteria yang telah ditetapkan peneliti dalam memenuhi fenomena serta masalah yang diajukan. Informan pada penelitian ini sebanyak 5 orang, pengumpulan data dilakukan 
dengan triangulasi data melalui wawancara, observasi dan survei secara daring dan luring, serta kajian pustaka.

\section{HASIL DAN PEMBAHASAN}

Proses pembelajaran jarak jauh (PJJ) semestinya semakin memudahkan akses masyarakat memperoleh pendidikan yang sama dan merata di mana pun mereka berada. Namun, dalam praktiknya, pembelajaran jarak jauh (PJJ) menjadi tantangan tersendiri bagi seluruh pihak baik itu pendidik, peserta didik bahkan para orang tua. Para pendidik merasa khawatir terhadap rancangan program pembelajaran (RPP) kurang tersampaikan dengan baik. Begitupun dengan peserta didik yang memiliki kesulitan dalam mengikuti proses pembelajaran jarak jauh (PJJ), yang disinyalir lebih banyak tugas sementara pemahaman tentang konteks pembelajaran belum mereka kuasai dengan baik.

Di dalam proses pembelajaran jarak jauh (PJJ), proses pembelajaran pasti menunjukkan perilaku pencarian informasi. Meskipun sebelum hadirnya pembelajaran jarak jauh (PJJ), pencarian informasi sudah akrab dengan aktivitas siswa dalam pemenuhan informasi. Pemenuhan informasi berkaitan dengan pembelajaran sebelum hadirnya pandemi sebagian besar menggunakan koleksi perpustakaan. Sedangkan saat ini, siswa SMAN 1 Cicalengka mengakui bahwa pemenuhan informasi di masa pandemi meningkat lebih tinggi dibandingkan sebelumnya. Kebutuhan informasi semakin meluas terkait proses pemilihan pembelajaran, motivasi, hobi, kesehatan, program studi bahkan lowongan pekerjaan.

Wilson (2000) mengungkapkan bahwa perilaku pencarian informasi sebagai salah satu konsekuensi dalam memenuhi kebutuhan dalam pencapaian tujuan. Setiap individu dapat berinteraksi dengan apapun baik itu manual maupun berbasis komputer. Wilson (2006) juga mengungkapkan bahwa perilaku ini memiliki kemungkinan besar didasari oleh pemenuhan kepuasan atas kebutuhan manusia (fisiologis, afektif dan 
kognitif). Akan tetapi hal tersebut tidak dapat dipastikan secara tetap menjadi pemicu pencarian informasi, masih banyak faktor lain seperti personal, interpersonal dan lingkungan yang memengaruhi.

Perilaku pencarian informasi ini dipengaruhi oleh perkembangan teknologi yang semakin berkembang pesat diungkapkan secara jelas oleh Ohtoshi dan Gottschalg-Duque (2016). Perkembangan tersebut tentunya memberikan perubahan perilaku pencarian informasi. Mereka melakukan konstruksi atas model pencarian informasi yang bersumber pada teori yang berkaitan untuk mendapatkan model yang sesuai pada perubahan ini seperti pada gambar 1 . Hal ini memberikan kemudahan dalam melakukan identifikasi secara menyeluruh terkait bagaimana dan mengapa perilaku pencarian informasi terjadi pada siswa yang mengalami kendala belajar secara mendalam.

\section{Information User (Pengguna}

\section{Informasi)}

Seorang pengguna informasi tentunya ditentukan dari profil serta karakteristik yang dimilikinya. Berdasarkan model pencarian informasi Ohotshi dan GottschalgDuque, bahwa informasi pengguna memiliki profil tersendiri. Profil tersebut dapat diidentifikasi dari karakteristik pengguna yaitu karakteristik demografi dan juga tipe personaliti yang digunakan oleh MyersBriggs. Tipe kepribadian Myers and Myers (1995) yang seringkali dikenal dengan 16 Personalities atau MBTI. Mereka mengembangkan tipe kepribadian Carl Jung dengan mengkombinasikan empat fungsi psikologis utama yang meliputi extrovert dan introvert, sensing dan intuiting, feeling dan thinking, judging dan perceiving. Tipe kepribadian yang dimiliki informan adalah ISFJ, ESFJ, ENFJ, INFJ dan ENFP.

Seorang ISFJ (Introvert, Sensing, Feeling, Judging) merupakan tipe introvert sensing. Dia sangat sistematis dan teliti, dapat bertanggung jawab dengan maksimal dan pekerja keras, sabar dan detail serta tentunya mudah beradaptasi dengan baik. ESFJ (Extrovert, Sensing, Feeling, Judging) 
Published by Program Studi Perpustakaan dan Ilmu Informasi

dan ENFJ (Extrovert, Intuiting, Feeling,

Judging) merupakan seorang ekstrovert

feeling memiliki kepribadian yang hangat, bijaksana, peka, teliti, teratur, idealis dan setia kepada lingkungannya. Dia memiliki ketegasan sekeras baja, cerdas dalam mengatasi masalah, percaya diri dalam mencapai titik terbaik dalam bidang apapun, memiliki wawasan yang sangat luas serta cenderung memilih pekerjaan yang mengasah inspirasinya merupakan kepribadian yang dimiliki INFJ (Introvert, Intuiting, Feeling, Judging) dengan introvert intuitifnya. Sedangkan
ENFP (Extrovert, Intuiting, Feeling, Judging) tipe ekstrovert intuitive ini merupakan seorang yang mandiri, kreatif, tanggap dalam penyelesaian masalah, mudah bergaul, memiliki semangat tinggi dan menyukai suasana baru.

Hasil wawancara dari ke lima informan bahwa mereka memiliki latar belakang pendidikan yang sama yaitu Sekolah Menengah Atas dengan usia 16, 17, 18 dan 19 tahun. Untuk perbandingan jenis kelamin perempuan sejumlah empat orang dan 1 orang lakilaki, digambarkan pada tabel berikut:

Tabel 1. Karakteristik Informan: 5 Siswa SMAN 1 Cicalengka

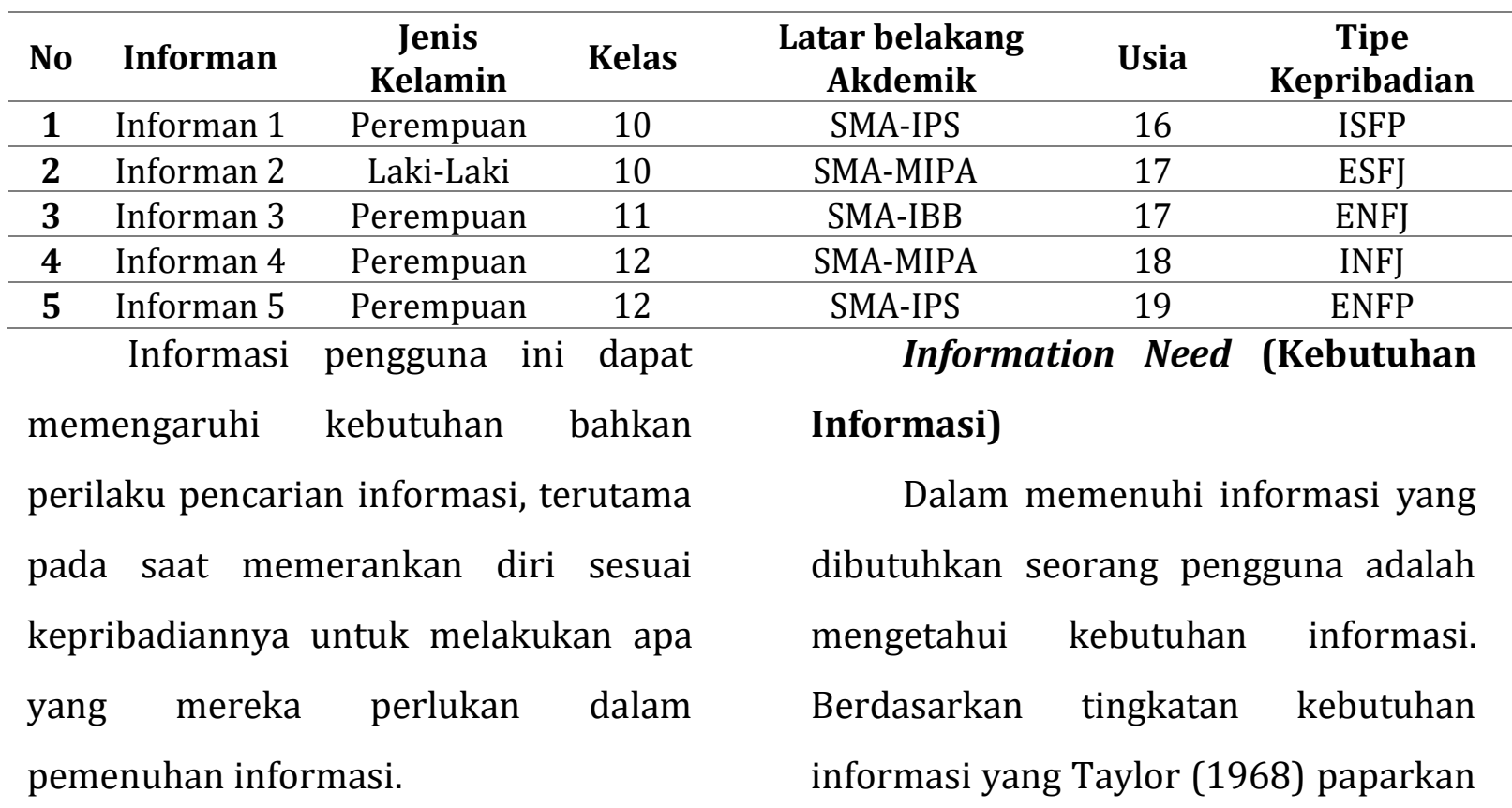


Published by Program Studi Perpustakaan dan Ilmu Informasi

(visceral, concious, adapted dan formalized), pemaparan atas pertanyaan yang diajukan menghasilkan data bahwa siswa mengalami tingkatan kebutuhan informasi yang berbeda-beda. Bagi ISFP dan ENFJ berada pada tahap concious, informasi merupakan suatu kebutuhan ketika pembelajaran dan kehidupan berlangsung bahkan ketika terdapat arahan untuk mengerjakan tugas. Ia menyadari bahwa terdapat informasi tertentu dalam membantu menyelesaikan tugas serta permasalahan yang dihadapi. Informan ESFJ berada pada tahap visceral, dimana ia masih belum memahami secara penuh kebutuhan informasi. Ia baru bisa memahami ketika mengalami korelasi dengan apa yang terjadi. Informan INFJ dan ENFP berada dalam tahap adapted, sudah sangat jelas mereka memahami terkait kebutuhan informasi terhadap materi pembelajaran di masa pandemi ini. Mereka juga memahami terkait informasi sebagai alat penyelesaian masalah di masa depan, seperti perkuliahan, pekerjaan atau permasalahan kehidupan sehari-hari lainnya. Hanya saja informan INFJ lebih teliti dalam mengidentifikasi kebutuhan informasinya serta memahami lebih jelas sumber informasi mana yang perlu digali.

Kebutuhan informasi yang dirasakan oleh kelimanya sebagian besar memiliki persamaan yaitu terkait materi pembelajaran, motivasi, kesehatan, hobi, perkuliahaan bahkan lowongan pekerjaan. Mereka melakukan pencarian informasi terkait materi pembelajaran sebagai penunjang dalam menyelesaikan permasalahan baik itu pemahaman diri terhadap materi bahkan penyelesaian tugas yang diberikan oleh guru. Pencarian informasi terkait kesehatan, motivasi dan hobi sebagai pengalih perhatian atas kendala yang sedang dihadapi yaitu jenuh, bosan bahkan merasa lelah terhadap jadwal yang sama. Selain itu pencarian informasi perkuliahan dan pekerjaan untuk mempersiapkan masa depan. 
Information Seeking (Pencarian

\section{Informasi)}

Secara keseluruhan bahwa siswa SMAN 1 Cicalengka belum memahami secara tepat terkait strategi atau model pencarian informasi. Mereka melakukan pencarian informasi berdasarkan kebiasaan dan intuisi yang muncul dalam diri. Ohtoshi dan Gottschalg-Duque (2016) memilih model Ellis (1989) dalam model pencarian informasinya, karena merupakan salah satu model yang paling banyak dikutip dalam berbagai literatur terkait perilaku pencarian informasi. Tahapan yang terdapat pada model Ellis (1989) adalah starting, browsing, chaining, monitoring, diferenciating, extracting, verifying dan ending.

Siswa SMAN 1 Cicalengka melakukan starting sesuai dengan pemaparan model Ellis. Dominannya informasi yang dicari terkait pembelajaran, contohnya melakukan pencarian terkait persamaan dan pertidaksamaan linear satu variabel. Mereka juga melakukan pencarian terkait penyebaran serta informasi terbaru terkait Covid-19. Melakukan pencarian terkait dunia kampus, perkuliahan dan pekerjaan. Tidak dapat dipungkiri pencarian jati diri melalui berbagai tes psikologi berjejaringpun dilakukan. Kemudian mereka memasuki tahap browsing atas topik tersebut melalui search engine yang dimiliki ponsel atau alat pendukung lainnya. Umumnya mereka memilih hasil pencarian teratas untuk memenuhi rasa penasaran yang muncul atas permasalahan tadi.

Setelah ditelusuri mereka tidak melakukan chaining, yaitu mencari informasi atas sumber rujukan yang ditemukan dalam salah satu website tadi. Mereka hanya berpindah ke dalam hasil pencarian lain dan melanjutkan aktivitasnya ke dalam tahap monitoring yaitu menganalisis kesesuaian informasi yang didapatkan. Untuk proses differentiating sendiri mereka tidak melakukannya secara rinci, hanya fokus melakukan pengelompokkan berdasarkan topik yang didapatkan. Terkadang mereka juga melakukan penandaan terhadap informasi, 
berjaga-jaga suatu waktu informasi tersebut akan diperlukan kembali.

Sebagian besar siswa kurang memahami proses extracting, alasannya karena mereka belum memahami terkait domain yang tepat atas informasi yang diperlukannya. Mereka yang belum memahami tentunya memilih secara cepat informasi yang dirasa sesuai tanpa melakukan verifikasi terhadap hasil, lalu memutuskan untuk selesai. Akan tetapi bagi mereka yang sudah paham terkait domain yang memuat berbagai materi pembelajaran, tentu akan melakukan verifikasi kebenaran teori yang ditemukan. Seperti melakukan verifikasi dengan hasil lain dengan domain pendidikan, verifikasi terhadap latar belakang penulis bahkan melakukan verifikasi terhadap guru bersangkutan, sehingga informasi yang didapatkan sesuai kebutuhan dalam menyelesaikan tugas persamaan dan pertidaksamaan linear satu variabel, dll.

Pada pembelajaran jarak jauh (PJJ) di masa pandemi Covid-19 ini, sebagian besar siswa mengandalkan sumber informasi yang terdapat pada berbagai search engine. Alasannya karena kemudahan informasi yang didapatkan dengan hanya mengetikkan topik yang diperlukan, dalam hitungan detik semua muncul dalam satu layar. Sebagian dari mereka juga masih mengandalkan fasilitas yang diberikan perpustakaan dalam pemanfaatan koleksi perpustakaan yaitu buku paket, dengan alasan kurang percaya diri ketika melakukan pencarian informasi secara berjejaring. Sangat dikhawatirkan menemukan teori atau informasi yang kurang sesuai dengan yang seharusnya. Kemudian beberapa dari mereka juga terkadang memutuskan untuk bertanya melalui media whatsapp kepada guru terkait, jika tidak memahami pelajaran.

\section{Information Use (Penggunaan}

\section{Informasi)}

Lima kategori penggunaan informasi yang diusulkan oleh Ohotshi dan Gottschalg-Duque yaitu: pemecahan masalah, pembelajaran, penyimpanan, pengambilan keputusan dan pertukaran informasi, diungkapkan oleh Taylor (1996) dan Choo (2003). 
Sebagai contoh, bahwa pencarian informasi terkait persamaan dan pertidaksamaan linear satu variabel menggiring pengguna untuk memanfaatkan informasi dalam proses pembelajaran. Membantu siswa dalam melakukan pemecahan masalah terkait tugas yang disediakan guru sebagai ajang latihan. Kemudian pencarian informasi terkait penyebaran serta informasi terbaru terkait Covid-19 memberikan akses kepada pengguna untuk melakukan pertukaran informasi, pemecahan masalah bahkan pengambilan keputusan. Seperti untuk mematuhi protokol kesehatan ketika hendak keluar rumah, berbagi informasi terbaru terkait virus Covid19 kepada teman bahkan bersikap waspada dengan mematuhi protokol kesehatan. Penggunaan informasi sebagai penyimpanan untuk digunakan di masa mendatang seperti pencarian informasi dunia kampus, perkuliahan, pekerjaan dan tes psikologi berjejaring. Informasi tersebut juga dapat berperan sebagai rujukan dalam pengambilan keputusan untuk memberikan langkah yang tepat dalam menata masa depan.

\section{PENUTUP}

\section{Simpulan}

Perilaku pencarian informasi sudah melekat pada aktivitas pemenuhan informasi seluruh lapisan masyarakat, khususnya dalam dunia pendidikan. Pandemi Covid-19 merupakan salah satu dorongan kuat bagi peserta didik SMAN 1 Cicalengka dalam mengakses informasi yang diperlukannya termasuk ruang lingkup pembelajaran. Pada masa pandemi Covid-19 ini peningkatan kebutuhan informasi siswa meningkat tajam sehingga memengaruhi juga perilaku pencarian informasi. Siswa merupakan pengguna informasi yang memiliki profil serta karakteristik unik yang memengaruhi proses pencarian informasi.

Kebutuhan informasi yang dirasakan para siswa pada masa pandemi Covid-19 ini terkait materi pembelajaran, motivasi, kesehatan, hobi, perkuliahaan bahkan lowongan pekerjaan. Mereka memiliki tingkatan tersendiri atas kesadaran terhadap kebutuhan informasi sebelum melakukan pencarian informasi. 
Sayangnya dalam proses pencarian informasi tersebut, sebagian siswa belum memahami strategi yang tepat sehingga mendapatkan hasil yang kurang maksimal. Sebagian besar pencarian informasi dilakukan secara berjejaring, meskipun tidak meninggalkan koleksi perpustakaan sebagai penunjang belajar dan juga guru sebagai fasilitator di sekolah. Penggunaan informasi juga dilakukan secara bijaksana dalam mengatasi berbagai masalah yang dihadapi baik itu berperan sebagai pemecahan masalah, pembelajaran, penyimpanan, pengambilan keputusan dan pertukaran informasi.

Harapannya, para siswa dapat mempelajari lebih lanjut terkait strategi pencarian informasi ini untuk mendapatkan hasil yang maksimal. Begitupun dengan guru sebagai pembimbing dalam dunia pendidikan, diharapkan mampu berkolaborasi dengan pustakawan untuk mengarahkan peserta didik dalam mengakses, mendapatkan, memahami dan menyimpulkan informasi yang didapat sesuai dengan kebutuhannya.
Sehingga peserta didik dan guru dapat mengembangkan diri secara kognitif, afektif dan psikomotor.

\section{DAFTAR PUSTAKA}

Covid-19.go.id. 2020. "Data Sebaran Covid-19." Retrieved (https://covid19.go.id/).

Myers, Isabel Briggs, and Peter B. Myers. 1995. “Gifts Differing: Understanding Personality." USA Davies-Black Publishing 215.

Ohtoshi, Paulo Hideo, and Cláudio Gottschalg-Duque. 2016. “A New Model of Information Behavior Based on Semantic Modeling." Proceedings of the Association for Information Science and Technology 53(1):1-5. doi: 10.1002/pra2.2016.1450530108 1.

Ridlo, Muhammad Rasyid, Ida Mariani Pasaribu, and Herry Fernando Tarigan. 2020. "Perilaku Pencarian Informasi Mahasiswa Tingkat Akhir Fakultas Ekonomi Dan Ilmu Sosial Di Perpustakaan Universitas Sari Mutiara Indonesia." LIBRARIA: Jurnal 


\section{Info Bibliotheca}

Jurnal Perpustakaan dan Ilmu Informasi

Published by Program Studi Perpustakaan dan Ilmu Informasi FBS Universitas Negeri Padang, Indonesia

Perpustakaan 7(1):91. doi: 10.21043/libraria.v7i1.5678.

Shenton, Andrew K., and Naomi V. HayGibson. 2011. "Modelling the Information-Seeking Behaviour of Children and Young People: Inspiration from beyond LIS." Aslib Proceedings: New Information Perspectives 63(1):57-75. doi: 10.1108/00012531111103786.

Susilana, Rudi. 2012. "Modul Penelitian: Penelitian Kualitatif." Direktori FIP. Retrieved (https://www.google.com/url?sa $=t \& r c t=j \& q=\& e s r c=s \&$ source $=w e$ $\mathrm{b} \& \mathrm{~cd}=\& \mathrm{cad}=\mathrm{rja} \& u a c t=8 \& \mathrm{ved}=2 \mathrm{ah}$
UKEwi_qOzfqYvuAhU6ILcAHX7A

CBw4ChAWMAB6BAgEEAI\&url=h ttp\%3A\%2F\%2Ffile.upi.edu\%2FD irektori\%2FFIP\%2FJUR._KURIKU LUM_DAN_TEK._PENDIDIKAN\%2 F196610191991021-).

Wilson, T. D. 2000. "Human Information Behavior." Informing Science 3(2):49-55. doi: 10.28945/576.

Wilson, T. D. 2006. “On User Studies and Information Needs." Journal of Documentation 62(6):658-70. doi: 10.1108/00220410610714895. 